\title{
European Integration, Economy and Corruption in the Western Balkans
}

\author{
Emi Malaj \\ PhD candidate, University of Vlora, Faculty of Economy, \\ Department of Economics
}

\begin{abstract}
The European Union countries and institutions have constantly contributed to the European integration process of the Western Balkan countries. Albania, Serbia, Montenegro and the Republic of North Macedonia are official candidates for EU membership. Chapters and accession negotiations have been opened with Montenegro and Serbia, whereas Kosovo and Bosnia and Herzegovina are potential candidate countries. Poverty, unemployment and corruption are probably the most common problems that Western Balkan citizens face. Corruption, in itself, does not lead to poverty, but it stimulate poverty through indirect channels by affecting economic, social, political and administrative conditions. Both, the enhancement of business climate for private investors, and a higher level of integration with the European Union will decrease unemployment and will boost economic growth. Authorities should follow concrete policies in order to encourage private sector investment, increase regional integration, and create new jobs. The future of the Western Balkans is in the European Union.
\end{abstract}

Keywords: European integration, economy, corruption, Western Balkans, poverty.

\section{Introduction}

\section{European integration}

The Western Balkans region includes Kosovo, Albania, Bosnia and Herzegovina, North Macedonia, Montenegro and Serbia. Kosovo is actually a potential candidate for European Union (EU) membership ${ }^{1}$. In 2008 the EU confirmed its willingness to assist the economic and political development of the country through a European perspective. The EU constantly contributes to the stability in Kosovo through the EULEX rule of law mission and the respective Special representative. On April 2016, the Stabilisation and Association Agreement between the EU and Kosovo entered into force. On July 2018, the European Commission confirmed that Kosovo has fulfilled all outstanding visa liberalisation conditions. The EU countries and institutions, especially the European Commission, play a key role in the reconstruction and development of the country. The EU has initially financed emergency relief actions and reconstruction of Kosovo, whereas now focuses on country's institutions, economic growth and European integration. Table 1 shows EU financial allocation for Kosovo for the period 2007-2019.

\footnotetext{
${ }^{1}$ See https://ec.europa.eu/neighbourhood-enlargement/countries/.
} 


\begin{tabular}{|l|l|l|l|l|l|l|l|}
\hline Year & 2007 & 2008 & 2009 & 2010 & 2011 & 2012 & 2013 \\
\hline IPA I & $€ 68.3 \mathrm{M}$ & $€ 184.7 \mathrm{M}$ & $€ 106.1 \mathrm{M}$ & $€ 67.3 \mathrm{M}$ & $€ 68.7 \mathrm{M}$ & $€ 68.8 \mathrm{M}$ & $€ 107.2 \mathrm{M}$ \\
\hline Year & 2014 & 2015 & 2016 & 2017 & 2018 & 2019 & 2020 \\
\hline IPA II & $€ 66.05 \mathrm{M}$ & $€ 66.5 \mathrm{M}$ & $€ 70.05 \mathrm{M}$ & $€ 73 \mathrm{M}$ & $€ 90.5 \mathrm{M}$ & $€ 86.36 \mathrm{M}$ & \\
\hline
\end{tabular}

Table 1. Financial allocation for Kosovo for the period 2007-2019. Source: https://ec.europa.eu/.

Albania is actually a candidate country for EU membership. The country was firstly identified as a potential EU candidate during the Thessaloniki European Council summit in June 2003. On April 2018, the European Commission confirmed its unconditional recommendation to open accession negotiations with Albania, whereas on June 2018, the EU Council sets out the path towards opening accession negotiations. On March 2020, the Council decided to open accession negotiations with Albania. This was the result of country's reform efforts in the last years and acknowledgement of the EU for the efforts made and the progress achieved on Albania's accession road ${ }^{1}$. The EU Delegation to Albania constantly promotes the typical European values, including democracy and the rule of law. The EU Delegation maintains an active and continuous dialogue with the country's authorities on human rights protection and cooperates with other important international organisations. The EU also provides support to civil society organisations in Albania, through funding opportunities and public awareness activities.

Bosnia and Herzegovina is actually a potential candidate for EU membership. The EU is contributing to the stability of the country through the EUFOR/Althea mission. On Jun 2012, the EU and Bosnia and Herzegovina launched the High Level Dialogue on the Accession Process; on June 2015, the Stabilisation and Association Agreement between EU and Bosnia and Herzegovina entered into force. The Delegation of the European Union to Bosnia and Herzegovina was established in 1996. The EU delegation promotes the progress in the Stabilisation and Association Process, and a stable, multi-ethnic country. It offers support in the political process to institutions at all levels, especially in the areas of the rule of law and security sector reform. North Macedonia is actually a candidate country for EU membership. On April 2018, the European Commission confirmed the unconditional recommendation to open accession negotiations with the country. On March 2020, the General Affairs Council opened accession negotiations with the country and endorsed the Commission Communication on a revised methodology "Enhancing the accession process - A credible EU perspective for the Western Balkans". North Macedonia was the first Western Balkan country to sign the Stabilisation and Association Agreement with the EU, that entered into force in April 2004. The EU continuously supports the civil society organisations in the country. The EU provides relevant financial assistance to civil society projects through the Instrument for Pre-accession. Montenegro is also a candidate country for EU membership. The country applied for EU membership in 2008, two years after the declaration of independence from the State Union of Serbia and Montenegro. On October 2007, Montenegro signed a Stabilisation and Association Agreement and an Interim Agreement on trade and trade-related issues with the EU. On May 2010, the Stabilisation and Association Agreement entered into force. On December 2009, Montenegrin citizens started to travel without visas in the Schengen area. On January 2008, agreements on trade and trade-related matters, visa facilitation and readmission entered into force. The accession negotiations with the country were opened in

\footnotetext{
${ }^{1}$ See https://eeas.europa.eu/delegations/albania/6953/albania-and-eu_en.
} 
2012. The Mission of Montenegro to the EU in Brussels conducts the diplomatic relations between the country and the EU. Serbia is actually a candidate country for EU membership. On June 2013, the European Council endorsed the Commission's recommendation to open negotiations with Serbia. European Council confirmed Serbia as a candidate country in 2012. On September 2013, the Stabilisation and Association Agreement between Serbia and the EU entered into force. On December 2013, the European Council adopted the negotiating framework with the country ${ }^{1}$.

\section{Economy and corruption: literature review}

Franičević (2004) analyzed the problems of legitimacy of post-socialist reforms and increased inequality and poverty levels. The author focuses on the countries of South East Europe, which have many common characteristics. These countries face a poor economic development and show basic disequilibria, fiscal, external and labour markets. South East Europe usually suffer from many institutional and democratic deficits; the reforms in these countries are slow. Many of them have also faced the challenge of building independent countries under extreme conditions of ethnic conflicts and war, which impact priorities and choices in reforms. High levels of corruption and serious fiscal deficits contributed to higher growth of inequality and poverty. Wallace and Latcheva (2006) considered the role of the informal economy in Central and Eastern European post-communist countries. The authors showed that in some countries the black economy is very important for supporting household incomes (Serbia and Croatia) and in other countries the household or social economies are predominant (Romania and Ukraine). In a considered third group of countries the formal economy predominates over other economies (Czech Republic and Hungary). According to Olters (2010), Albania's informal sector represents a considerable share of economic activities, and it could easily jeopardize the realization of country's medium-term goals of socio-economic development and European integration. Budgetary revenues are weak and formal private sector activities are discouraged by strained taxpayer relations and poor public services; inadequate tax enforcement; excessive permit and licensing requirements; the existence of a competitive disadvantage relative to informal market participants; and a weak public infrastructure. Informal activities are usually associated with an increased level of public corruption; officials accept bribes in exchange for protection or other favours to the detriment of the country. In a system rooted in high levels of corruption and bribery, economic incentives are discouraged and government officials and favoured private investors receive a larger part of public benefits or a lower share of the cost of public goods. This will lead to lower private investments, lower government revenues, and subsequently to an increased inequality and poverty.

According to Holmberg and Rothstein (2010), representative democracy works poorly as a cure against poverty or large-scale economic inequalities. Empirical analysis showed that this is true especially for poor countries, including Albania and other Eastern European countries. Empirical analysis tested the relation between variables related to the quality of government, including levels of corruption and the rule of law, and poverty or inequality. The main conclusion from the empirical test is that quality of government is relevant for reducing absolute poverty among poor countries and for reducing relative economic inequalities among rich as well as among poor countries, also after controlling for democracy. Shera (2011) analyzed the impact of corruption on economic growth across 22 developing countries for the period of 2001-2012. Based on the empirical results, the panel data analyses reveal that there

${ }^{1}$ See https://ec.europa.eu/neighbourhood-enlargement/countries/. 
is a statistically significant negative relationship between corruption and economic growth. The relationship is directly related to inclusion of other determinants of economic growth. According to Hysa (2011), Western Balkan countries are characterized by a series of obstacles in economic, politics and social aspects. The author studied the relationship between corruption level and human development. Hysa (2011) estimated a regression and compared the degree of the relationship for each Western Balkan country during 2002-2010. The main result of this study is that the relationship between corruption and human development is found to be strong in Former Yugoslav Republic of Macedonia, Serbia, Montenegro and Albania. Croatia exhibits a weak relationship whereas the relationship in Bosnia and Herzegovina's case is not significative. Qerimi and Sergi (2012) discussed and analysed data related to economic freedom and corruption. The authors tested the validity of results of different sources on same issue, as well as the accuracy and credibility of those sources. They considered middle-income economies, upper middle-income countries; or societies in transition that range between flawed democracies (Croatia and Macedonia) and hybrid regimes (Albania, and Bosnia and Herzegovina), under the categorisation of the Index of Democracy. Results showed that countries which have scored the highest results in economic freedom were the same countries that had the most relevant progress achieved in eliminating corruptive behaviour. A larger level of economic freedom increases the success in fighting corruption as a critical measure of institutional performance.

Rontos, Salvati, Sioussiouras and Vavouras (2013) proposed a classification of the perceived corruption levels of Mediterranean countries according to key political, economic, and social variables. Empirical evidence showed the key role of corruption in various countries by analyzing differences in their respective values on a corruption perceptions index. The variables used by the authors include additional data such as gross national income per person in purchasing power parities, a political rights index, a civil liberties index, and a non income human development index. According to Rontos, Salvati, Sioussiouras and Vavouras (2013), policies against corruption should target a complex ensemble of driving factors not limited to the economic characteristics of an individual country and should include social political, cultural, institutional, and territorial considerations. According to Bayar and Ozturk (2017), the global wealth has increased considerably and decreases in income inequality and poverty have been experienced in the recent years. Income inequality and poverty have still stayed at dramatic levels. The authors investigated the causal interaction among corruption, income inequality, and poverty in Central and Eastern European Union transition economies, during 2005-2016 period, by employing panel causality test. Empirical results revealed a one-way causality from poverty to corruption and also a one-way causality from income inequality to poverty. Basna (2018) analyzed the relation between income inequality and corruption in Europe. The author focused on post-communist European countries. In the case of post communist countries, the relation among corruption and income inequality are more complicated than in the rest of Europe; different approach in fighting corruption must be followed.

\section{Facts and data}

Poverty, unemployment and corruption are probably the most common problems that Western Balkan citizens face. Corruption, in itself, does not lead to poverty, but it stimulate poverty through indirect channels by affecting social-economic, political and administrative conditions (Ildirar and Iscan, 2016). Corruption can be correlated with the economic growth and affect unemployment and income distribution; this will bring poverty. Figure 1 shows the 
Gross Domestic Product growth (annual \%) during 2015-2019 for the Western Balkans countries. Serbia experienced the highest annual growth for $2019(4,187)$, whereas the respective smallest value was recorded for Albania $(2,214)$. Gross Domestic Product growth is the most common estimator of economic growth.

\begin{tabular}{|l|l|l|l|l|l|}
\hline Country & 2015 & 2016 & 2017 & 2018 & 2019 \\
\hline Albania & 2,219 & 3,315 & 3,802 & 4,071 & 2,214 \\
\hline Bosnia and Herzegovina & 3,088 & 3,146 & 2,118 & 3,716 & 2,583 \\
\hline North Macedonia & 3,856 & 2,848 & 1,082 & 2,720 & 3,551 \\
\hline Montenegro & 3,390 & 2,949 & 4,716 & 5,078 & 3,621 \\
\hline Serbia & 1,776 & 3,340 & 2,049 & 4,392 & 4,187 \\
\hline Kosovo & 4,095 & 4,071 & 4,226 & 3,816 & 4,172 \\
\hline
\end{tabular}

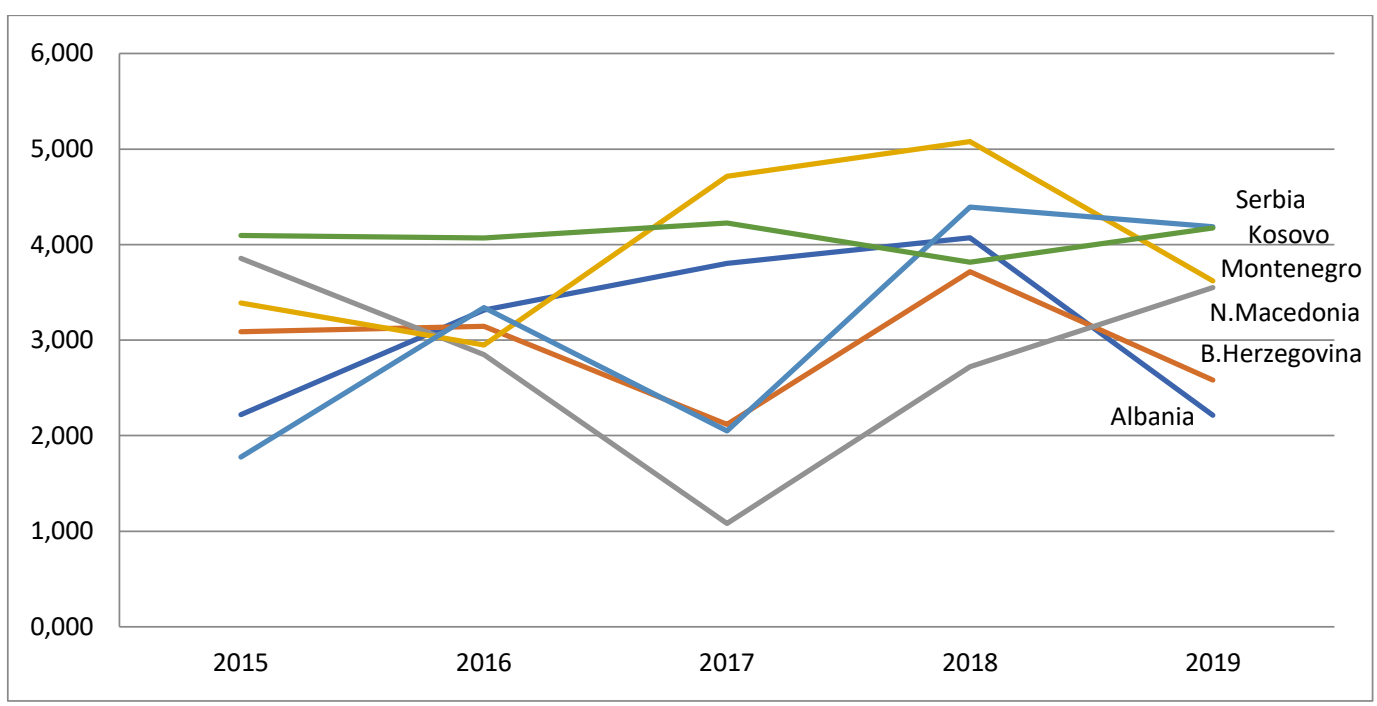

Figure 1. GDP growth (annual \%) during 2015-2019. Source: World Bank. Chart by author.

\begin{tabular}{|l|l|l|l|l|l|}
\hline Country & CPI score 2019 & Rank & Standard error & Lower Cl & Upper Cl \\
\hline Albania & 35 & 106 & 2,507669 & 30,88742 & 39,11258 \\
\hline Bosnia and Herzegovina & 36 & 101 & 1,952692 & 32,79758 & 39,20242 \\
\hline Kosovo & 36 & 101 & 0,8146842 & 34,66392 & 37,33608 \\
\hline North Macedonia & 35 & 106 & 3,56274 & 29,15711 & 40,8429 \\
\hline Serbia & 39 & 91 & 2,484553 & 34,92533 & 43,07467 \\
\hline Montenegro & 45 & 66 & 4,836292 & 37,06848 & 52,93152 \\
\hline
\end{tabular}

Many studies analyzed the effect of corruption on economic growth and the usual conclusion is that the former negatively affects the latter. Corruption negatively affect the quality of government services and the distribution of public expenditures. Corruption has a negative effect on poverty. Figure 2 shows the Corruption Perceptions Index in 2019 for the Western 
Balkans countries. Montenegro experienced the highest value for 2019 (45), whereas the respective smallest values were recorded for Albania and North Macedonia (35).

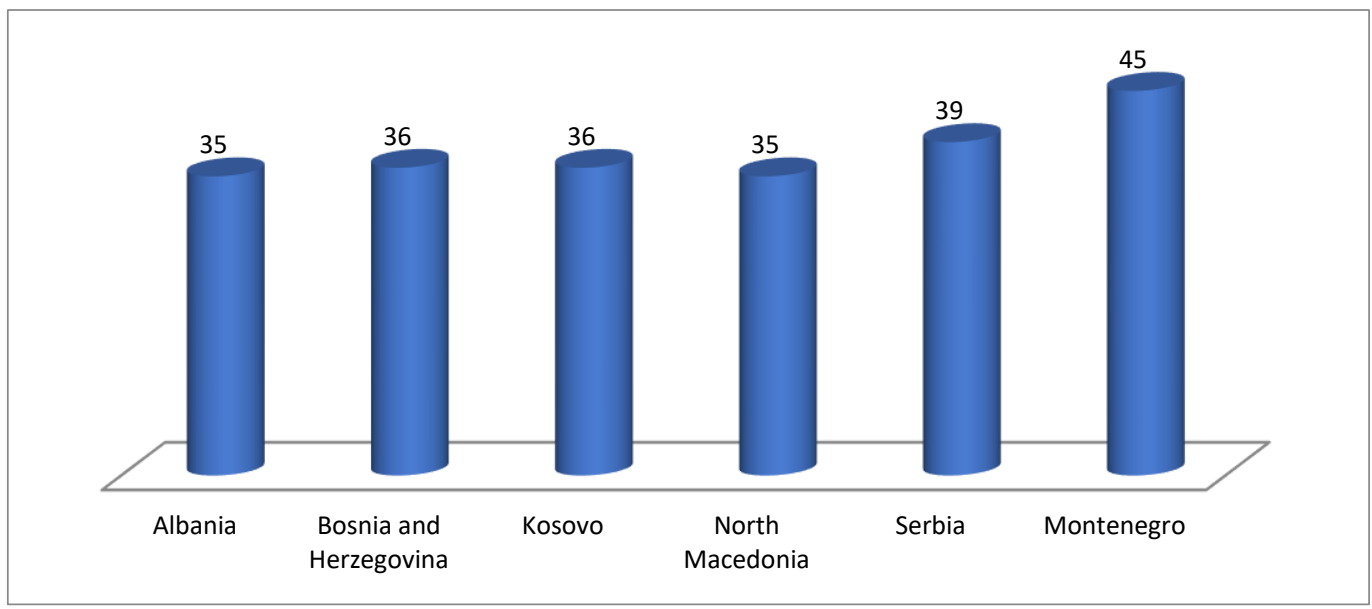

Figure 2. Corruption Perceptions Index in 2019 and the respective rank, standard error and confidence intervals. Source: Transparency International. Chart by author.

Table 2 shows the available poverty gap indexes at $\$ 3.20$ a day for the Western Balkan countries. This index is calculated as the mean shortfall in income or consumption from the poverty line $\$ 3.20$ a day (counting the non poor as having zero shortfall), expressed as a percentage of the poverty line. This measure reflects the depth of poverty as well as its incidence $^{1}$. Serbia experienced the highest value (in the available sample) for $2017(6,1)$, whereas the respective smallest values were recorded for Kosovo $(0,6)$.

\begin{tabular}{|l|l|l|l|l|l|}
\hline Country & 2013 & 2014 & 2015 & 2016 & 2017 \\
\hline Bosnia and Herzegovina & 0,1 & & & & \\
\hline Kosovo & 0,6 & 1 & 0,7 & 0,6 & 0,6 \\
\hline Montenegro & 3 & 2,4 & 2,2 & 2,5 & 2,2 \\
\hline North Macedonia & 4,4 & 3,9 & 4,3 & 3,6 & 3,6 \\
\hline Serbia & 5,7 & 6,6 & 5,1 & 6,3 & 6,1 \\
\hline Albania & & 3,2 & 2,2 & 2,5 & 2,2 \\
\hline
\end{tabular}

Table 2. Poverty gap at $\$ 3.20$ a day (2011 PPP) (\%). Source: World Bank. Table by author.

According to Gupta, Davoodi and Alonso-Terme (2002), an increase of one standard deviation in corruption increases the Gini coefficient of income inequality by about 11 points and income growth of the poor by about 5 percentage points per year. High and increasing corruption increases income inequality and poverty. Policies that reduce corruption will most likely reduce income inequality and poverty as well. Table 3 shows the available GINI indexes for the Western Balkan countries. Data are based on primary household survey data obtained from government statistical agencies and World Bank country departments.

\footnotetext{
${ }^{1}$ https://datacatalog.worldbank.org/poverty-gap-320-day-2011-ppp-2.
} 


\begin{tabular}{|l|l|l|l|l|l|l|l|l|l|l|l|l|}
\hline Country & $\begin{array}{l}200 \\
5\end{array}$ & $\begin{array}{l}200 \\
6\end{array}$ & $\begin{array}{l}200 \\
7\end{array}$ & $\begin{array}{l}200 \\
8\end{array}$ & $\begin{array}{l}200 \\
9\end{array}$ & $\begin{array}{l}201 \\
0\end{array}$ & $\begin{array}{l}201 \\
1\end{array}$ & $\begin{array}{l}201 \\
2\end{array}$ & $\begin{array}{l}201 \\
3\end{array}$ & $\begin{array}{l}201 \\
4\end{array}$ & $\begin{array}{l}201 \\
5\end{array}$ & $\begin{array}{l}201 \\
7\end{array}$ \\
\hline $\begin{array}{l}\text { B. } \\
\text { Herzegovina }\end{array}$ & & & 33,1 & & & & 33 & & & & & \\
\hline Kosovo & 31,2 & 30,3 & & & 31,8 & 33,3 & 27,8 & 29 & 26,3 & 27,3 & 26,5 & 29 \\
\hline Montenegro & 30,2 & 30 & 31,4 & 30,5 & 31 & 28,9 & 30,8 & 32,3 & 32,4 & 31,9 & & \\
\hline N. Macedonia & & & & & 42,8 & 40,2 & 39,4 & 38,1 & 36,2 & 35,2 & 35,6 & \\
\hline Serbia & & & & & & & & 39,8 & 39,8 & 39,2 & 39,6 & \\
\hline Albania & 30,6 & & & 30 & & & & 29 & & & & \\
\hline
\end{tabular}

Table 3. GINI index (World Bank estimate). Table by author.

The Human Development Index (HDI) is a summary measure of average achievement in key dimensions of human development: a long and healthy life, being knowledgeable and have a decent standard of living. The HDI is the geometric mean of normalized indices for each of the three dimensions ${ }^{1}$. The health dimension is estimated by life expectancy at birth, the education dimension is measured by mean of years of schooling for adults aged 25 years and more and expected years of schooling for children of school entering age. The standard of living dimension is estimated by gross national income per capita. The HDI employ the logarithm of income, in order to reflect the decreasing importance of income with increasing GNI. The scores for the three HDI dimension indices are then aggregated into a composite index using geometric mean. An increase in income affects Human Development Index, and also decrease poverty. Figure 3 shows the HDI during 2000-2017 for Western Balkan countries. Montenegro experienced the highest value for 2017 (0,814), whereas the respective smallest values was recorded for Kosovo (0,742).

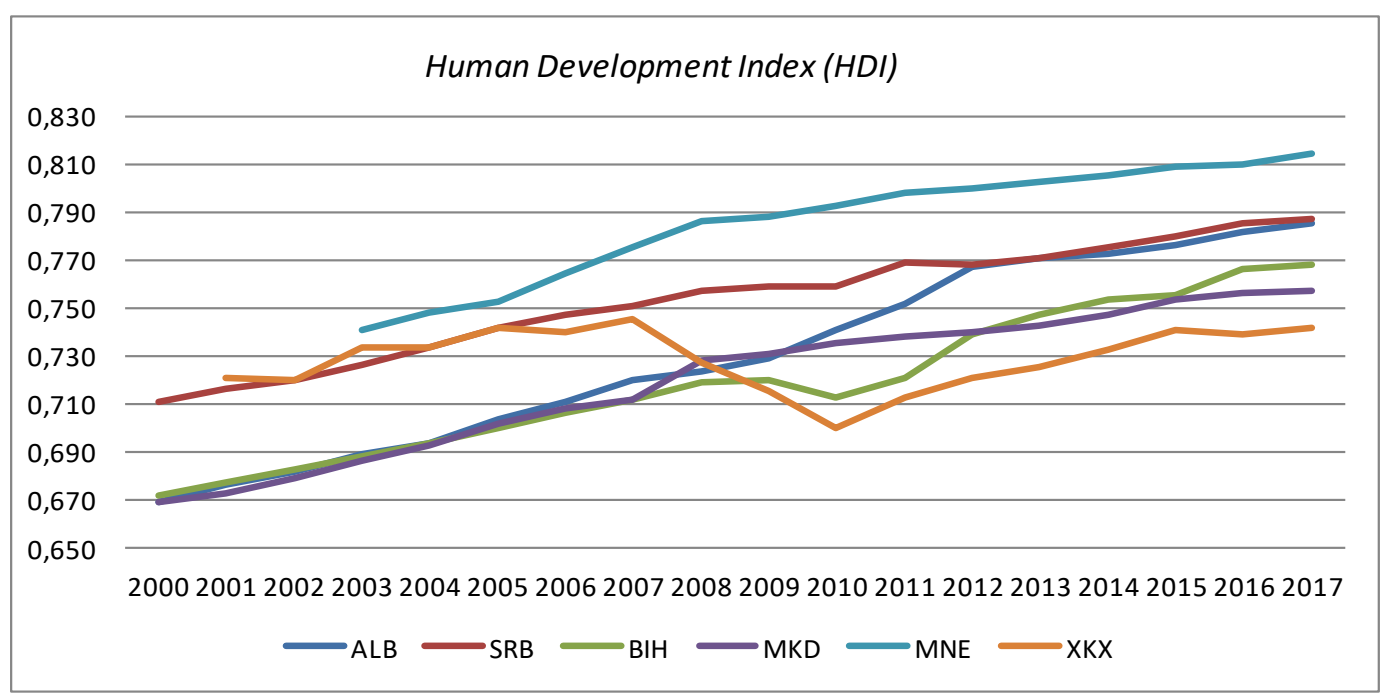

\footnotetext{
${ }^{1}$ http://hdr.undp.org/en/content/human-development-index-hdi.
} 


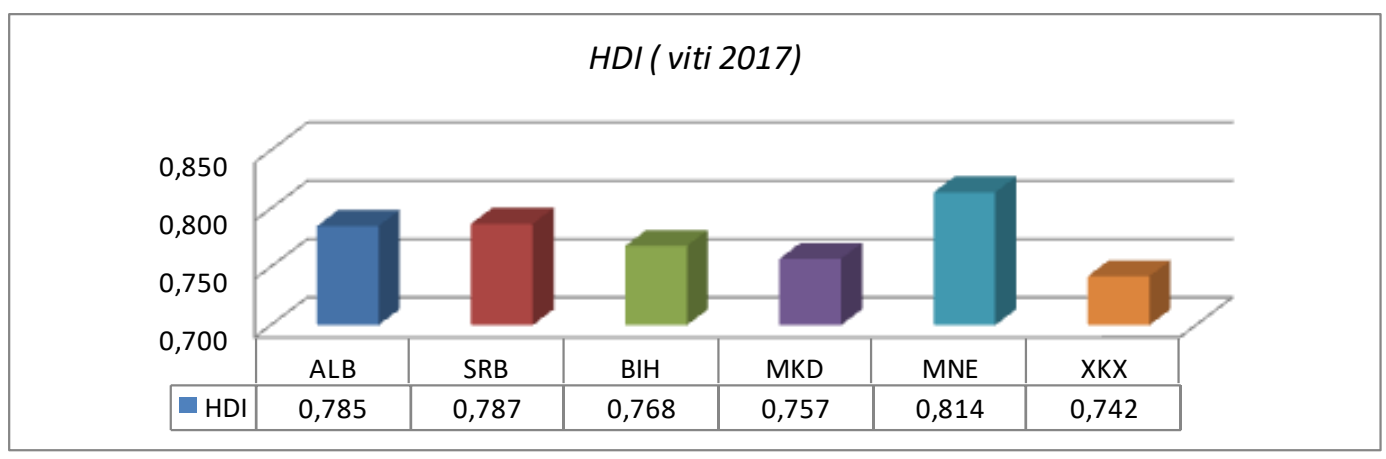

\section{Figure 3. Human Development Index during 2000-2017. Source: UNDP (United Nations Development Programme). Charts by author.}

According to a World Bank (2017) report ${ }^{1}$, it will take around six decades for income levels in the Western Balkans to achieve those of the European Union. This confirmation is true if economies in the Western Balkans will continue to grow at the average speed of the last 20 years. The economic growth can be stimulated through the implementation of structural reforms and the promotion of macroeconomic stability. Authorities should follow concrete policies in order to encourage private sector investment, increase regional integration, and create new jobs. Policymakers should focus on increasing exports, investments, and employment.

\section{Concluding remarks}

The European Union countries and institutions have constantly contributed to the European integration of the Western Balkan countries. Albania, Serbia, Montenegro and the Republic of North Macedonia are official candidates for EU membership. Chapters and accession negotiations have been opened with Montenegro and Serbia, whereas Kosovo and Bosnia and Herzegovina are potential candidate countries. Poverty, unemployment and corruption are probably the most common problems that Western Balkan citizens face. Corruption, in itself, does not lead to poverty, but it stimulate poverty through indirect channels. A higher regional integration will stimulate exports as a share of Gross Domestic Product. The public sector is the most important driver of the Western Balkans economy; private investments in these countries need to increase. Both, the enhancement of business climate for private investors, and a higher level of integration with the European Union will decrease unemployment and will boost economic growth. Policymakers should also remove obstacles to employment for marginalized groups. This will lead to a higher participation in the labor market. The future of the Western Balkans is in the European Union.

\section{References}

[1] Bayar Y., \& Ozturk, O. (2017). Corruption, Income Inequality and Poverty in Central and Eastern European Union Countries: A Panel Causality Analysis.

\footnotetext{
${ }^{1}$ https://openknowledge.worldbank.org/bitstream/handle/10986/28894/ACS22690.pdf.
} 
[2] Franičević, V. (2004). Real and perceived inequality, poverty and well-being in South East Europe: challenges of the welfare state and democracy. Workshop 'Poverty in the Mediterranean Area', University of Thrace.

[3] Gupta, S., Davoodi, H., \& Alonso-Terme, R. (2002). Does corruption affect income inequality and poverty?. Economics of governance, 3(1), 23-45.

[4] Holmberg, S., \& Rothstein, B. (2010). Quality of Government is Needed to Reduce Poverty and Economic Inequality. QoG Working paper series, 2010(3), 3.

[5] Hysa, E. (2011). Corruption and human development correlation in Western Balkan countries. EuroEconomica, 30(4).

[6] Ildırar, M., \& Iscan, E. (2016). Corruption, poverty and economic performance: Eastern Europe and central Asia case. International Journal of Economics and Finance Studies, 7(2), 27-41.

[7] Kristyna Basna, K. (2018). Income Inequality and the Level Of Corruption In Europe: Specificities Of Post-Communist Countries. OECD Global Anti-Corruption and Integrity Forum, March 2018.

[8] Olters, J. P. (2010). Albania's informal economy: an impediment to economic development. International Monetary Fund avaiable at: www. bankofalbania. org/web/pub/JanPeterOlters_240_1. pdfon, 18.

[9] Qerimi, Q., \& Sergi, B. S. (2012). The effects of economic freedom on institutional performance in the Western Balkans countries. International Journal of Business Governance and Ethics, 7(1), 18-36.

[10] Rontos, K., Salvati, L., Sioussiouras, P., \& Vavouras, I. (2013). Mediterranean countries and corruption: Political, economic, and social factors. Mediterranean Quarterly, 24(1), 81-97.

[11] Shera, A. (2011). Corruption and the Impact on the Economic Growth. Journal of Information Technology \& Economic Development, 2(1).

[12] Wallace, C., \& Latcheva, R. (2006). Economic transformation outside the law: corruption, trust in public institutions and the informal economy in transition countries of Central and Eastern Europe. Europe-Asia Studies, 58(1), 81-102. 